Надія САБАТ, кандидат педагогічних наук, доиент кафедри соиіальної педагогіки та соиіальної роботи ДВНЗ "Прикарпатський національний університет імені Василя Стефаника"

Наталія САБАТ, кандидат педагогічних наук, викладач кафедри соиіальної педагогіки та соиіальної роботи ДВНЗ "Прикарпатський національний університет імені Василя Стефаника"

\title{
ДУХОВНО-МОРАЛЬНІ ЦІННОСТІ У ПРОФЕСІЙНОМУ СТАНОВЛЕННІ ОСОБИСТОСТІ МАЙБУТНЬОГО СОЦІАЛЬНОГО ПРАЦІВНИКА
}

\author{
Nadia SABAT, Candidate of Pedagogical Sciences, Docent at the Depart- \\ ment of Social Pedagogy and Social Work at State Higher Educational Es- \\ tablishment "Vasyl Stefanyk Precarpathian National University" \\ Natalia SABAT, Candidate of Pedagogical Sciences, Teacher at the Depart- \\ ment of Social Pedagogy and Social Work at State Higher Educational Es- \\ tablishment "Vasyl Stefanyk Precarpathian National University"
}

\section{SPIRITUAL AND MORAL VALUES IN THE PROFESSIONAL DEVEL- OPMENT OF THE PERSONALITY OF THE FUTURE SOCIAL WORKER}

У статті розкрито роль духовноморальних цінностей у професійному становленні особистості майбутнього соціального працівника. Охарактеризовано соціальну роботу як особливий вид діяльності, що базується на принципах гуманізму, віри у власні сили людини, визнання права кожного на самовизначення, створення рівних можливостей. Доведено, що у практичній діяльності соціального працівника разом 3 професійними знаннями вагому роль відіграють особистісно-моральні якості: чесність, совість, об'єктивність, справедливість, тактовність, пильність і спостережливість, толерантність, витримка i самовладання, доброта, любов до людей, терпіння, комунікабельність, оптимізм; розкрито сутність основних з них. Простежено зв'язок духовно-моральних цінностей соціального працівника з його ціннісними орієнтаціями. Охарактеризовано засоби формування духовно-моральних цінностей у процесі фахової підготовки майбутнього соціального працівника.

Ключові слова: духовно-моральні цінності, етика, духовність,

(C) Н. Сабат, Н. Сабат мораль, соціальний працівник, професійна підготовка.

Summary. The article reveals the role of the spiritual and moral values in the professional development of the personality of the future social worker. The social work is described as a special type of activity based on the principles of humanism, belief in human rights, recognition of the right of every person to self-determination, and the creation of equal opportunities. It is proved that in the social worker's practical activity, along with professional knowledge, his personal and moral qualities play an important role, namely: honesty, conscience, objectivity, justice, tact, vigilance and observation, tolerance, endurance and self-control, kindness, love for people, patience, sociability, optimism; the essence of the main ones was revealed. The link between the spiritual and moral values of the social worker and his value orientations was traced. The means for the formation of spiritual and moral values in the process of the future social worker professional training were described.

Key words: spiritual and moral values, ethics, spirituality, moral, social worker, professional training.

Мета: охарактеризувати роль духовно-моральних цінностей у про- цесі професійного становлення майбутнього соціального працівника.

Постановка проблеми в загальному вигляді. У сучасних змінних умовах значна кількість людей стикається 3 емоційною нестабільністю, тривогою, втратою життєвих орієнтирів. Однією з причин цього явища $€$ руйнування загальнолюдських, духовно-моральних ідеалів, що веде до дезорієнтації особистості зокрема i суспільства загалом. Тому все частіше і науковці, і практики звертаються до перевірених часом традицій, пошуку шляхів утвердження духовноморальних орієнтирів як запоруки розвитку суспільства, створення умов для гармонійного розвитку всіх категорій населення. Саме соціальні працівники повинні утверджувати в середовищі соціально слабких верств населення почуття захищеності, віри в гуманність, моральність суспільства, складовою якого вони $\epsilon$.

У цьому процесі вагому роль відводять соціальному працівникові, метою діяльності якого $є$ створення умов для саморозвитку особистості, а одним із головних завдань - підтримка людини, стимулювання іiї до активної життєдіяльності, наснаження до саморозвитку. Сьогодні в Україні відбувається інтенсивний розвиток соціальної роботи як нового виду 
професійної діяльності і як спеціальності в системі вищої освіти. Функціонують факультети, відділення, школи соціальної роботи в університетах, інститутах, коледжах; формується система різновидностей спеціалізацій. Професія соціального працівника пройшла еволюцію від піклувальника, опікуна до професійно підготовленого фахівця, здатного активізувати внутрішній потенціал людини, допомогти їй подолати різного роду проблеми, активно контролювати власне життя. Зважаючи, що соціальний працівник працює з різними категоріями клієнтів у системі людина-людина, в усі часи, разом із професійними, велику увагу приділяли його особистісним якостям. Історичні джерела засвідчують: результативність соціальної роботи значною мірою залежала від гуманності, доброти, емпатійності тих осіб, які працювали у сфері надання соціальних послуг. Питання формування духовно-моральних якостей у майбутніх фахівців соціальної сфери $\epsilon$ особливо важливим сьогодні, в умовах зростання кількості та розширення категорій клієнтів - отримувачів соціальних послуг. Духовність, моральність упродовж усієї історії українського народу забезпечували розвиток особистості, сприяли формуванню іiі індивідуальності, усвідомленню свободи. I це надто важливо в час переоцінки соціальних орієнтирів.

Закон України "Про вищу освіту" трактує вищу освіту як сукупність систематизованих знань, умінь і практичних навичок, способів мислення, професійних, світоглядних і громадянських якостей, моральноетичних цінностей, інших компетентностей [9]. Першочерговим завданням сучасної вищої педагогічної освіти в Україні є переорієнтування змісту освіти від наукової поінформованості до формування культури й духовності, що бачиться запорукою виживання людства і вирішення найболючіших проблем особистості.

Аналіз досліджень і публікацій. Актуальність проблеми формування у фахівців духовно-моральних цінностей підтверджується багатьма дослідженнями в різних наукових галузях. Теоретико-методологічні засади плекання духовно-моральних цінностей у студентів вищих закладів освіти обгрунтовано в наукових роботах I. Беха, М. Свтуха, І. Зязюна, Г. Михайлишин, О. Сухомлинської та інших. Так, Г.
Михайлишин доводить домінуючу роль світоглядних цінностей у контексті потреб суспільної модернізації [4], характеризує цінності освіти як засіб досягнення мети суспільного поступу [5, с. 202]. Учені, котрі вивчають питання професійної підготовки соціальних працівників (Р. Вайнола, I. Грига, I. Звєрєва, А. Капська, I. Козубовська, Л. Міщик, В. Поліщук, I. Трубавіна та ін.), наголошують на взаємозв'язку та поєднанні професійних, особистісних, духовного-моральних якостей майбутніх фахівців. У наукових працях ідеться про необхідність не лише здобуття студентами професійної підготовки, а й формування особистісної готовності дотримуватися професійно-етичних норм і принципів. Найчастіше акцентується на таких якостях фахівця соціальної сфери, як гуманістична спрямованість особистості, особиста і соціальна відповідальність, загострене почуття добра і справедливості, почуття власної гідності, повага гідності іншої людини, терпимість, ввічливість, порядність, емпатійність, готовність зрозуміти інших і прийти їм на допомогу [7, c. 276$].$

Проведений аналіз наукової літератури свідчить про грунтовну розробленість проблеми професійного становлення майбутнього соціального працівника, роль у цьому процесі ціннісних орієнтирів. Утім, окреслені дослідження не вичерпують усіх аспектів багатогранної проблеми, що вимагає подальшого вдосконалення змісту, технологій навчання і виховання майбутніх працівників соціальної сфери, спрямованих на формування в них духовно-моральних цінностей, високого рівня духовно-моральної культури.

Виклад основного матеріалу дослідження. Соціальна робота як професія виникла на основі благодійної діяльності - християнської богоугодної справи, позаяк випливала із сутності Бога. Любов до людей, співчуття, милосердя, доброзичливість були необхідними умовами надання допомоги нужденним і лягли в основу сучасного формулювання принципів соціальної роботи. Остання є особливою галуззю професійної діяльності і базується на системі цінностей, що сформувалися у процесі становлення моральних принципів та норм поведінки фахівців, служать підгрунтям будь-яких професійних дій.

У соціальній роботі поняття "цінність" вживається для позначення принципів і норм, що виявляють морально-естетичні установки соціальної роботи [8, с. 146]. Це традиції, переконання, норми поведінки та принципи, які вважаються бажаними певною культурою, групою людей чи індивідом [1, c. 206]. О. Рудакевич визначає цінності як позитивну чи негативну значимість об'єктів навколишнього світу для людини, класу, нації, суспільства в цілому, що характеризуються не властивостями, а залученням до сфери суспільства, інтересів і потреб, соціальних відносин; критерії та способи оцінювання цієї значимості передаються через моральні принципи, норми, ідеали, установки, цілі [10, с. 69]. Духовно-моральні цінності базуються на традиціях етики - системи моральних принципів та уявлень стосовно правильної поведінки порівняно 3 неправильною, i, як результат, відповідної концепції поведінки, якої дотримуються окремі люди, групи, представники певної професії чи культури [1, c. 64]. Моральні цінності вважають вагомим поняттям етики. За їх допомогою характеризується значення для суспільства й людини соціально-історичних явищ. Моральні цінності відтворюють діяльнісно-зацікавлене ставлення людини до світу й самої себе, а також проблематичність реалізації актуальних моральних потреб у реальному житті. Добро цінується тому, що $є$ зло, моральний вчинок виступає цінністю завдяки тому, що існує реальна можливість його іншого варіанту [13, с. 292].

Соціальний працівник - професійно підготовлений фахівець, котрий має необхідну кваліфікацію у сфері соціальної роботи та виконує різноманітні види соціальної роботи. Соціальний працівник допомагає людям вирішувати проблеми, створюючи необхідні ресурси, забезпечує взаємодію між людьми чи між людиною та середовищем загалом, підвищує відповідальність організацій за людину, впливає на соціальну політику. Професія соціального працівника спрямована на соціальну спеціалізовану діяльність, об'єктивно необхідну для функціонування державних i громадських систем соціальної допомоги різним категорія населення, для реалізації життєвих, потенційно закладених у кожній людині сил для самозбереження і саморозвитку $[2, c$. $181]$. 
Духовно-моральні цінності покладені в основу документа "Етика соціальної роботи: принципи і стандарти", прийнятого в липні 1994 року в Коломбо (Шрі-Ланка). У ньому проголошуються етичні принципи і стандарти соціальних працівників стосовно клієнтів та колег. Як відомо, кожна людина унікальна, потребує підходу 3 позицій моралі; має право на свободу в задоволенні власних потреб, не зачіпаючи права інших, і зобов'язана зробити свій внесок у підвищення добробуту суспільства.

Основні знання в галузі професійної діяльності соціальний працівник отримує у процесі навчання в середньому спеціальному навчальному закладі, закладі вищої освіти. Майбутній фахівець осягає сутність духовно-моральних цінностей, отримує дані про їхній зміст і функціонування в суспільстві, порівнює власні цінності з професійними, соціально вагомими і коректує свою моральну позицію. Важливо, щоб соціальні працівники як професійна група були не лише поінформованими про систему духовно-моральних цінностей, a й виступали їх носіями. Адже професіонал повинен відокремлювати особисті почуття й потреби від професійних відносин, бути готовим передавати знання та вміння іншим, прагнути до високих стандартів особистої і професійної етики. Соціальний працівник, який керується духовно-моральними цінностями, успіх своєї роботи вбачає в облагородженні світу людей, котрі з різних причин опинилися у складних життєвих обставинах.

Соціальна робота $є$ особливим видом соціальної діяльності, спрямованої на формування і реалізацію гуманістичних цінностей та ідеалів, у результаті якої відбувається перетворення соціальної дійсності, створення можливостей досягнення гуманістичного ідеалу і благополуччя особистості та суспільства. Їі фундаментом слугують принципи прав людини та соціальної справедливості [2, $c$. $176]$.

Професійна діяльність соціального працівника надзвичайно різнопланова й охоплює широкий діапазон існуючих у суспільстві соціальних відносин і процесів. Клієнтами соціального працівника є представники соціально вразливих верств населення (діти, молодь, жінки, національні меншини, люди похилого віку, неповні та багатодітні сім'ï); люди, які "випали" із суспільного життя або піддаються гнобленню (бездомні, діти вулиці, особи, які відбували покарання в місцях позбавлення волі, які страждають від залежностей); люди, котрі потрапили у скрутну життєву ситуацію (безробітні, біженці, особи, що зазнали насильства). Зважаючи на багатоцільовий і різноплановий характер професійної діяльності, соціальний працівник має володіти певними професійними знаннями та професійно зумовленими особистісними якостями. Робота 3 людьми вимагає неабияких зусиль, такту i, передусім, поваги до людини, іiі потреб та проблем. Тому важливим є не лише загальнокультурний, інтелектуальний, а й моральний потенціал соціального працівника. Фахівець повинен бути професійно тактовним, викликати симпатію, довіру, зберігати професійну таємницю, дотримуватися делікатності в обговоренні інтимних питань життя клієнта. Виконуючи професійний обов'язок, слід виявляти спокій, доброзичливість, уважність.

У процесі соціальної роботи виникають моральні взаємини, тобто сукупність залежностей і зв'язків між соціальним працівником та клієнтом, між самими соціальними працівниками, між соціальними працівниками і соціальним оточенням клієнта, між соціальними працівниками та об'єднаннями й організаціями. У професійній діяльності соціальні працівники часто опиняються перед складними моральними проблемами, що спонукає їх діяти відповідно до своїх моральних переконань, адже не всі ситуації достатньо повно врегульовані законодавством. Усе це актуалізує наявність у соціального працівника чіткої системи духовно-моральних цінностей як запоруки ефективності його професійної діяльності.

Успішність соціальної роботи визначається застосуванням низки етичних принципів, насамперед, принципу гуманізму. Він потребує поваги до людини, визнання гідності іiі особи, доброзичливого ставлення, а також передбачає наявність у соціального працівника таких якостей, як ввічливість, тактовність, скромність, чуйність.

Уже за своєю природою соціальна робота орієнтована на гуманістичні цілі. Соціальні працівники у професійній діяльності керуються положеннями: життя людини є найвищою цінністю; право на повагу й достойне життя має кожна людина незалежно від іiі національних, расових, релігійних, вікових, статевих, індивідуальних чи соціальних особливостей. Згідно з принципом гуманізму наркоман, злочинець чи психічно хворий розглядається, насамперед, як людина, що потрапила у складні життєві обставини і потребує допомоги. Принцип гуманності визначає пріоритет загальнолюдських цінностей, що сягають корінням у родинне середовище, та фундаментальні основи моральності [2, с. 178]. Утім, у сучасних умовах надання соціальної допомоги потребуючим ускладнюється недосконалістю законодавчої бази, недостатнім ресурсним забезпеченням соціальної сфери. Але навіть в умовах складної соціальноекономічної ситуації соціальні працівники повинні протидіяти порушенню прав людини, упроваджувати в життя принцип соціальної справедливості.

Ще одним важливим принципом професійної діяльності соціального працівника є визнання права кожної людини на самовизначення, тобто жити згідно зі своїми бажаннями й потребами. Тому в сучасній практиці соціальної роботи необхідно відмовитися від нав'язування клієнту своїх думок та позицій, спонукати його до самостійного вирішення проблем, використовуючи принцип наснаження. Тобто діяльність соціального працівника має бути спрямована на розкриття потенційних можливостей клієнта, розвиток його психологічних, моральних, соціальних якостей, які дозволили б йому самостійно вирішувати власні проблеми.

Надання соціальних послуг особистості незалежно від віку, національності, походження, соціального статусу, сфери зайнятості, місця проживання, релігійної приналежності забезпечує принцип створення рівних можливостей [2, с. 181]. Для його реалізації соціальний працівник повинен неупереджено й об'єктивно ставитися до всіх клієнтів, надавати однакову допомогу, не зважаючи на те, розділяє він погляди клієнта чи ні.

Високий рівень духовно-моральних якостей соціального працівника забезпечує принцип етичності, який відображає характер діяльності та спрямований на коректну обробку інформації і збереження конфіденційності [2, с. 179]. Фахівець не має розголошувати отриману від клієнта інформацію; коректно задавати запи- 
тання, керуючись інтересами клієнта; підводити клієнта до пошуку оптимального вирішення кризової ситуації. Слід дотримуватися принципів соціальної справедливості, захисту й недоторканності клієнтів, професійної таємниці; поважати право клієнта на компетентне роз'яснення його прав і суті особистої справи.

У практичній діяльності соціального працівника поряд із професійними знаннями вагому роль відіграють особистісно-моральні якості, які $\epsilon$ визначальним фактором ефективності практичної роботи. Вони неабияк впливають на систему міжособистісних взаємин. Тому оптимальне поєднання професійних компетентностей з високою духовно-моральною культурою соціального працівника $\epsilon$ запорукою його продуктивної діяльності.

У психолого-педагогічній літературі йдеться про моральні, духовні, духовно-моральні якості особистості 3 акцентуванням на їхній вагомій ролі у професійній діяльності. Наприклад, В. Теслюк виокремлює такі: гуманність, доброта, терпимість, справедливість, тактовність, емпатійність, скромність, відповідальність [14, c. 12]. Л. Моргай до такого переліку відносить чесність, совість, об'єктивність, справедливість, тактовність, пильність і спостережливість, толерантність, витримку й самовладання, доброту, любов до людей, самокритичність, адекватність самооцінки, терпіння, комунікабельність, оптимізм [6, с. 202].

Необхідною умовою ефективного виконання професійних обов'язків соціальним працівником $\epsilon$ совість як почуття моральної відповідальності за свою поведінку, потреба діяти відповідно до особистих уявлень про добро, благо і справедливість. Для перетворення совісті в дієвий регулятор поведінки особистість має зазнавати морального виховання, яке i здійснюється під час професійної підготовки в навчальному закладі. В. Логвиненко зазначає, що совість неможливо виховати без комплексного впливу на особистість, на її ціннісні орієнтації, моральну свідомість. Для того, щоб совість стала внутрішнім помічником ефективного виконання функціональних обов'язків, працівник повинен прийняти систему цінностей соціальної роботи, мати чіткі уявлення про моральну дію i володіти високою культурою $[3, c$. $53]$.
Проаналізовані вище якості можна об'єднати узагальнювальним терміном "духовність". Його вживають для відображення вищих сторін внутрішнього світу людини, які виявляються у людяності, сердечності, доброті, відвертості, теплоті, відкритості до інших осіб. Духовність грунтується на широті поглядів, ерудиції, культурі, загальному розвитку особистості. Втрата духовності прирівнюється до втрати людяності. Тривала криза в окремої особистості призводить до деградації останньої. Духовність несумісна з жорстокістю, егоїзмом, орієнтацією на матеріальні вигоди [12, с. 501-502]. Духовні цінності визначають соціальну активність i творчість у ставленні особистості до культури суспільства й кожного іiі носія. Такими цінностями визначають свободу, братерство, працю, гуманність, солідарність, готовність особистості пожертвувати своїми благами заради благополуччя рідних, добробуту сім'ї, розквіту нації, що вважається критерієм соціальної вихованості особистості [11, с. 78].

Духовно-моральні цінності соціального працівника тісно пов'язані 3 його ціннісними орієнтаціями. Останні - вибіркова, дещо стійка система спрямованості інтересів і потреб особистості, направлена на певний аспект соціальних вартісностей. Детермінантами ціннісних орієнтацій особистості виступають матеріальні умови життєдіяльності, а також індивідуально-типові риси, нахили, здатності і здібності людини. Ціннісні орієнтації істотно впливають на стиль мислення і життя індивіда, перебіг емоційних та мотиваційних процесів, а також формування інтересів особистості [12, с. 501-502].

Формуванню духовно-моральних цінностей сприяє зміст навчальних дисциплін, які вивчають майбутні соціальні працівники: "Етика соціальної роботи", "Основи родинного виховання", "Українська етнопедагогіка та етнопсихологія" тощо. Включенню студентів до різного виду спілкування, міжособистісних взаємин сприяє проходження практики: волонтерської, виробничої в ЦСССДМ, територіальних центрах. Процес формування духовно-моральних цінностей у майбутніх соціальних працівників значною мірою залежить від педагогів і наставників, які самі мають володіти високою моральною культурою, сповідувати цінності соціальної роботи, здійсню- вати цілеспрямований та опосередкований вплив на своїх підопічних. Удосконалення моральної культури, формування духовно-моральних цінностей має відбуватися комплексно із застосуванням різних форм навчання впродовж усього терміну підготовки. Великий виховний потенціал і тих форм, які сприяють залученню студентів до навчального процесу. Це, передусім, лекції-бесіди, лекції з розглядом конкретних ситуацій, проблемні лекції, дискусії, ділові ігри, мозкові атаки, бесіди за круглим столом, що максимально наближає до професійної специфіки, сприяє формуванню відповідних переконань, ціннісних орієнтацій, засвоєнню моделей моральної дії.

Висновки та перспективи подальших досліджень. Формування духовно-моральних цінностей займає вагоме місце у професійній підготовці майбутніх соціальних працівників, що відбувається у навчальновиховному процесі під впливом прикладу викладачів, соціального оточення та на основі соціальних взаємодій, набутих знань, індивідуальної діяльності особистості. Духовно-моральні цінності лежать в основі моральних норм. Щоб певне знання про моральну поведінку перетворилося на норму, якої соціальний працівник дотримуватиметься у професійній діяльності, духовно-моральні цінності повинні бути переосмислені особистістю, стати надбанням її моральної свідомості. Формуванню духовноморальних цінностей у професійній підготовці майбутніх соціальних працівників сприяють зміст навчальних дисциплін, проходження різних видів практики, проведення заходів, особиста участь студентів у соціальних акціях, приклад викладачів.

У подальшому дослідження 3 цієї теми можуть бути присвячені вивченню механізмів формування духовно-моральних цінностей у майбутніх соціальних працівників та розробці рекомендацій змістового, процесуального характеру для підвищення їхнього рівня.

\section{ЛІТЕРАТУРА}

1. Англо-український термінологічний словник-довідник із соціальної роботи / за ред. А. Журавського, I. Байбакової, Н. Гайдук. Львів, 2004. $214 \mathrm{c}$.

2. Енциклопедія для фахівців соціальної сфери / за заг. ред. проф. I. Д. 
Звєрєвої. Київ, Сімферополь : Універсум, 2012. $536 \mathrm{c.}$

3. Логвиненко В. М. Совість як категорія професійної етики соціального працівника. Соціальна робота в Україні: теорія і практика: наук.-метод. журнал. Київ : ТОВ Вид-во "Аспект-Поліграф", 2014. № 3-4. С. 4754.

4. Михайлишин Г. Й. Світоглядні пріоритети освітньої сфери в контексті потреб суспільної модернізації: монографія Івано-Франківськ : HAIP, $2012.374 \mathrm{c}$.

5. Михайлишин Г. Й. Цінності освіти як засіб досягнення мети суспільного поступу. Гуманітарний вісник Запорізької державної інженерної академії. 2011. № 47. С. 202209.

6. Моргай Л. А. Професійно-етична діяльність соціального працівника. Педагогічні науки: зб. наук. праць Херсонського держ. ун-ту. 2017. Вип. 78. T. 2. C. 200-203.

7. Невлева І. М., Соловйова Л. В. Теорія соціальної роботи: навч. посіб. Білгород : Кооперативна освіта, 2005. $431 \mathrm{c}$.

8. Понятійно-термінологічний словник з соціальної роботи / уклад. I. Козубовська, I. Мигович, В. Сагарда та ін.; заг. ред. І. Козубовської, І. Миговича. Ужгород : Мистецька лінія, 2001. 152 c.

9. Про вищу освіту: Закон України від 01.07.2014 р. № 1556-VII, редакція від 01.01.2019. URL: https:// zakon.rada.gov.ua/laws/show/1556-18

10. Рудакевич О. Духовність як узмістовлення професійної діяльності соціального працівника. Соціологічні студії. 2014. № 2. С. 68-73.

11. Соціальна робота. Кн. 1 : Актуальні проблеми теорії і практики на межі тисячоліть / за ред. В. П. Андрущенка. Київ : Ін-т вищої освіти АПН України; Держ. центр соц. служб для молоді УДСССМ, 2001. 342 с.

12. Соціальна робота: короткий енциклопедичний словник / авторський колектив: В. Андрущенко, В. Бех, В. Башкірєв, М. Вовканич та ін. Київ : ДЦССМ, 2002. Кн. 4.536 с.

13. Соціолого-педагогічний словник / за ред. В. В. Радула. Київ : ЕксОб, 2004. 304 c.

14. Теслюк В. М. Технології соціально-педагогічної діяльності: термінологічний словник-довідник. Київ : НАКККіМ, 2011. 145 c.

\section{REFERENCES}

1. A n h 1 o- - k r a i n s k y i terminolohichnyi slovnyk-dovidnyk iz sotsialnoi roboty / za red. A. Zhuravskoho, I. Baibakovoi, N. Haiduk. Lviv, 2004. 214 s.

2. Entsyklopediia dlia fakhivtsiv sotsialnoi sfery / za zah. red. prof. I. D. Zvierievoi. Kyiv, Simferopol: Universum, 2012. $536 \mathrm{~s}$.

3. Lohvynenko V. M. Sovist yak katehoriia profesiinoi etyky sotsialnoho pratsivnyka. Sotsialna robota $v$ Ukraini: teoriia i praktyka: nauk.-metod. zhurnal. Kyiv : TOV Vyd-vo "AspektPolihraf", 2014. № 3-4. S. 47-54.

4. Mykhailyshyn H. Y. Svitohliadni priorytety osvitnoi sfery $\mathrm{v}$ konteksti potreb suspilnoi modernizatsii: monohr. Ivano-Frankivsk : NAIR, 2012. $374 \mathrm{~s}$.

5. Mykhailyshyn H. Y. Tsinnosti osvity yak zasib dosiahnennia mety suspilnoho postupu. Humanitarnyi visnyk Zaporizkoi derzhavnoi inzhenernoi akademii. 2011. № 47. S. 202-209.
6. Morhai L. A. Profesiinoetychna diialnist sotsialnoho pratsivnyka. Pedahohichni nauky: zb. nauk. prats Khersonskoho derzh. untu. 2017. Vyp. 78. T. 2. S. 200-203.

7. Nevleva I. M., Soloviova L. V. Teoriia sotsialnoi roboty: navch. posib. Bilhorod : Kooperatyvnyi osvita, 2005. $431 \mathrm{~s}$.

8. Poniatiino-terminolohichnyi slovnyk z sotsialnoi roboty / uklad. I. Kozubovska, I. Myhovych, V. Saharda ta in.; zah. red. I. Kozubovskoi, I. Myhovycha. Uzhhorod : Mystetska liniia, 2001. $152 \mathrm{~s}$.

9. Pro vyshchu osvitu: Zakon Ukrainy vid 01.07.2014 r. № 1556-VII, redaktsiia vid 01.01.2019. URL: https:// zakon.rada.gov.ua/laws/show/1556-18

10. Rudakevych O. Dukhovnist yak uzmistovlennia profesiinoi diialnosti sotsialnoho pratsivnyka. Sotsiolohichni studii. 2014. № 2. S. 6873.

11. Sotsialna robota. Kn. 1 : Aktualni problemy teorii i praktyky na mezhi tysiacholit / za red. V. P. Andrushchenka. Kyiv : In-t vyshchoi osvity APN Ukrainy; Derzh. tsentr sots. sluzhb dlia molodi UDSSSM, 2001. 342 s.

12. Sotsialna robota: korotkyi entsyklopedychnyi slovnyk / avtorskyi kolektyv: V. Andrushchenko, V. Bekh, V. Bashkiriev, M. Vovkanych ta in. Kyiv : DTsSSM, 2002. Kn. 4. 536 s.

13. Sotsioloho-pedahohichnyi slovnyk / za red. V. V. Radula. Kyiv : EksOb, 2004. 304 s.

14. Tesliuk V. M. Tekhnolohii sotsialno-pedahohichnoi diialnosti: terminolohichnyi slovnyk-dovidnyk. Kyiv : NAKKKiM, 2011. 145 s.

Стаття надійшла 29.03.2019 р. 